\title{
Characterization of a Collective Action between Farmers' Organizations and Institutions in an Innovative Process to Face Liberalization in Costa Rica
}

\author{
Guy Faure*
}

\begin{abstract}
In Northern Costa Rica agricultural production conditions change very rapidly due to public policies that encourage the exportation of new crops according to the liberalization process imposed by the international context.
\end{abstract}

For many years, farmers' organizations at the local, regional and national levels have taken initiatives to respond to this new context and develop relationships with institutions (the Ministry of Agriculture, national universities, NGOs, international agencies, the private sector...) promoting innovations and attaining better access to information, training and financial resources. A research action program, Aid to Farmer's Organization of Northern Costa Rica, contributes to the strengthening of farmers' organizations and tries to induce a dynamic of change through the elaboration of a shared vision of peasant agriculture which means to produce safe food, protect natural resources, develop qualified local employment and defend rural culture.

This communication will analyze the dynamic of the collective action. This collective action is structured around different activities such as the exchange of experiences between farmers' organizations, the elaboration of a common vision on the future of family based agriculture between different actors, training for the members and leaders of organizations, designing and implementation of innovative projects...

This collective action induces the construction of new and useful knowledge, changes in the relationships between the actors, implementation of new institutional mechanisms and the development of new rules inside and outside of the organizations.

\section{The context}

In Costa Rica, peasant agriculture faces a deep crisis due to market liberalization and state withdrawal linked to public policies that encourage the export of non-traditional products and facilitate foreign investment. The impending implementation of the free trade agreement between United States and the Central American countries (CAFTA), the implementation of quality norms to address the requirements of the WTO, the States and buyers make it more difficult to preserve the place of small farmers in the market. This context encourages a strong rural emigration to cities and the extension of transnational farming to produce bananas, pineapples, oranges and wood. Nevertheless, the complex role of agriculture in Costa Rican society is questioned by some actors (farmers' organizations, public institutions, universities, ONGs...). The different useful functions of agriculture beyond food production, such as natural resource management to protect the biodiversity or employment creation to alleviate poverty should be considered. Within this analysis small-scale farmers have a place and farmers' organizations should play a strategic role to offer services to their members and to negotiate with other actors.

\footnotetext{
* CIRAD-Tera, 73 rue Jean-François Breton, 34398 Montpellier Cedex 5, France; email: guy.faure@cirad.fr
} 
For several years, the Ministry of Agriculture and Livestock $\left(\mathrm{MAG}^{\dagger}\right)$ has assisted smallscale farmers mainly through farmers' organizations. In the northern region, (Huetar Norte) some of these were created during the time of struggles for land access and after several years have evolved to improve agricultural production through inputs, credit deliveries and collective commercialization. Most of these were created by the institutions in response to the lack of public means or to implement activities identified by projects. A large number of small farmers' organizations now exist (around 400 and the MAG works with 150 of them). The majority of them face strong difficulties due to the current economic crisis, poor assistance from the public institutions or functional weaknesses. A diagnosis of farmers' organizations (Rodriguez 2003) pointed to the lack of participation inside the organizations, poor leadership capacities, the lack of management skills and few financial resources. Nevertheless, some strong farmers' organizations do currently exist, often linked to attractive markets (pineapple, ornamental plants, milk) and other smaller organizations addressing social issues.

To assist the farmers' organizations, the MAG, in collaboration with a French agricultural research institution $\left(\mathrm{CIRAD}^{\ddagger}\right)$ is conducting a research-action program to test new methods of strengthening farmers' organizations in order to encourage a change in northern Costa Rica peasant agriculture.

This communication will address some questions surrounding this process. Can the methods used really generate a collective action involving different actors to achieve common goals? What are the principles of this collective action? How is this collective action characterized? What are the main changes induced by the collective action?

\section{A research-action program to assist farmers' organizations}

Over a three year period the program proposed to achieve different objectives aimed at strengthening farmers' organizations in the Huetar Norte region through (i) the elaboration of a shared vision of peasant agriculture in the future from the point of view of the farmers' organizations and the participation of these farmers' organizations in the designing of public policies, (ii) capacity building activities directed toward some farmers' organizations (human and social capital) and assistance to some projects managed by the farmers' organizations.

This research-action program is devoted to train representatives from the farmers and members of the farmers' organizations, to address some short term problems at the level of the farmers' organizations (better internal functioning, conflict resolution, commercialization...), to facilitate exchanges and the union between farmers' organizations and reinforce negotiating power with public institutions, projects, and the private sector around a collective project of peasant agricultural development. Farmers' participation in the program designing, monitoring and evaluation is provided through different meetings and mechanisms.

\footnotetext{
${ }^{\dagger}$ Ministerio de Agricultura y Ganaderia

* Centre de Cooperation Internationale en Recherche Agronomique pour le Développement
} 
Shared vision of peasant agriculture in the future and participation in designing public policies

Workshops throughout the year are organized with a group of 10 to 15 representatives and technicians from farmers' organizations. The representatives are willing to work on this theme and have experience in negotiation with public institutions. Some of them have responsibilities in the regional or national farmers' organizations. Each workshop is devoted to a theme (the free trade agreement in Central America, agricultural and non-agricultural activities, farm diagnosis, the role of the farmers' organizations...) to analyze the situation, to identify the perspectives, to elaborate a common point of view on peasant agriculture in the future and to propose a plan of action including policy recommendations and a set of projects.

During this process, some meetings are programmed with grass-roots farmers' organizations to take into account the local needs, to include local community knowledge, and to facilitate a collective action with larger participation. National farmers' organizations participate in organizing these meetings.

At the same time the program facilitates the participation of farmers' representatives in different activities with other stake-holders through meetings with the Ministry of Agriculture to present projects, contacts with donors and different workshops organized by institutions on the future of the agriculture in Costa Rica.

Some special studies are carried out to gather useful information needed by the farmers and technicians concerning public policy history, diagnosis of farmers' organizations, regional farming system characteristics and the main characteristics of farms in the region from the point of view of the farmers through a participatory survey.

\section{Capacity building of farmers' organizations}

The program organized meetings at the grass-roots level with 10 to 20 farmers' organizations which are diversified in terms of activities (services around agricultural activities, preservation of the environment, rural tourism development), social categories (women's associations, youth groups), size (small; with around ten members to large; with up to 200 members) and geographical representation at the Huetar Norte regional level. The method includes participatory diagnosis, action plan designing, training program implementation according to demands and assistance to some activities or projects of the farmers' organizations. The work with each farmers' organization could be variable depending upon the needs and farmers' interests. The training programs deal with participation, leadership capacities, conflict resolution.... etc.

Technical assistance is provided to some of the organizations to resolve specific problems (planning yucca production according to the commercialization program of the farmers' organization, agricultural training at the farm level to fit the quality norms of markets, farm experiments on organic pineapple, organization of bean commercialization between different farmers' organizations).

\section{Why it is a collective action?}

A collective action is a line of action identified by different actors to achieve a common goal better reached through collective activities than individual initiatives. Many studies 
have addressed the difficult relationships between the individual and collective interests by taking into account the importance of moral values such as trust, reciprocity and reputation to understand a collective action (Elster 1990, Ostrom 1998). Nevertheless, the case of this research-action program is more complex because it addresses a set of objectives located at different levels. A collective action can be identified at the farmers' organization level, which aims to provide services to members, set up a project, or defend the interests of a specific group inside the rural community. At this level, it is important to analyze the interactions between individuals and the organization especially through the participation concept. At the regional level, another type of collective action emerges with broader objectives. The relationships involve different actors; individuals who participate in different activities with their own motivations, farmers' organizations with a broad set of objectives and sometimes with conflicts of interest, and institutions which deal with their own objectives. The construction of common objectives and the implementation of an action plan involving all these actors generate some questions on such an approach to induce relevant changes at the local and regional levels.

According to E. Ramirez et al. (2002), the research-action program has primary objectives that fit with a collective action. The authors mention the following objectives:

- Capacity building at an individual level (human capital) to improve personal skills. The activities contributing to this objective are the following: participatory diagnosis and training in some farmers' organizations, workshops on the future of the peasant agriculture, farmers' experiments...

- Empowerment of the farmers' organizations to better achieve their goals. The activities contributing to this objective are the following: participatory diagnosis, programming and monitoring process in some farmers' organizations...

- Network construction and social exchanges. The activities which contribute to this objective are the following: workshops within and between farmers' organizations, relationships and negotiation with others stakeholders...

- Creation of shared values and norms between individuals. The activities contributing to this objective are the following: working on the future of peasant agriculture, training and activities on the participation or on the roles of leaders...

Beyond this first level of objectives and according to the perspective of the same authors, this research-action program seeks to contribute to:

- Improve farmer's income through better market insertion. For example: through a bean commercialization project designed between three farmers' organizations, the adaptation of agricultural practices to fit the new norms imposed by the market and international agreements in the case of the ornamental plants, pineapple and yucca, farmers' experiments to develop better technologies which could increase competitiveness

- Modify the relationships within farmers' organizations between members by strengthening the participation through workshops and targeted training

- Influence public policies to improve development opportunities and to reduce the exclusion processes through the elaboration of a peasant agriculture proposal, development of relationships with other stakeholders, participation and negotiation in different forums... 
Figure 1 shows the complexity of this collective action and therefore to analyze it.

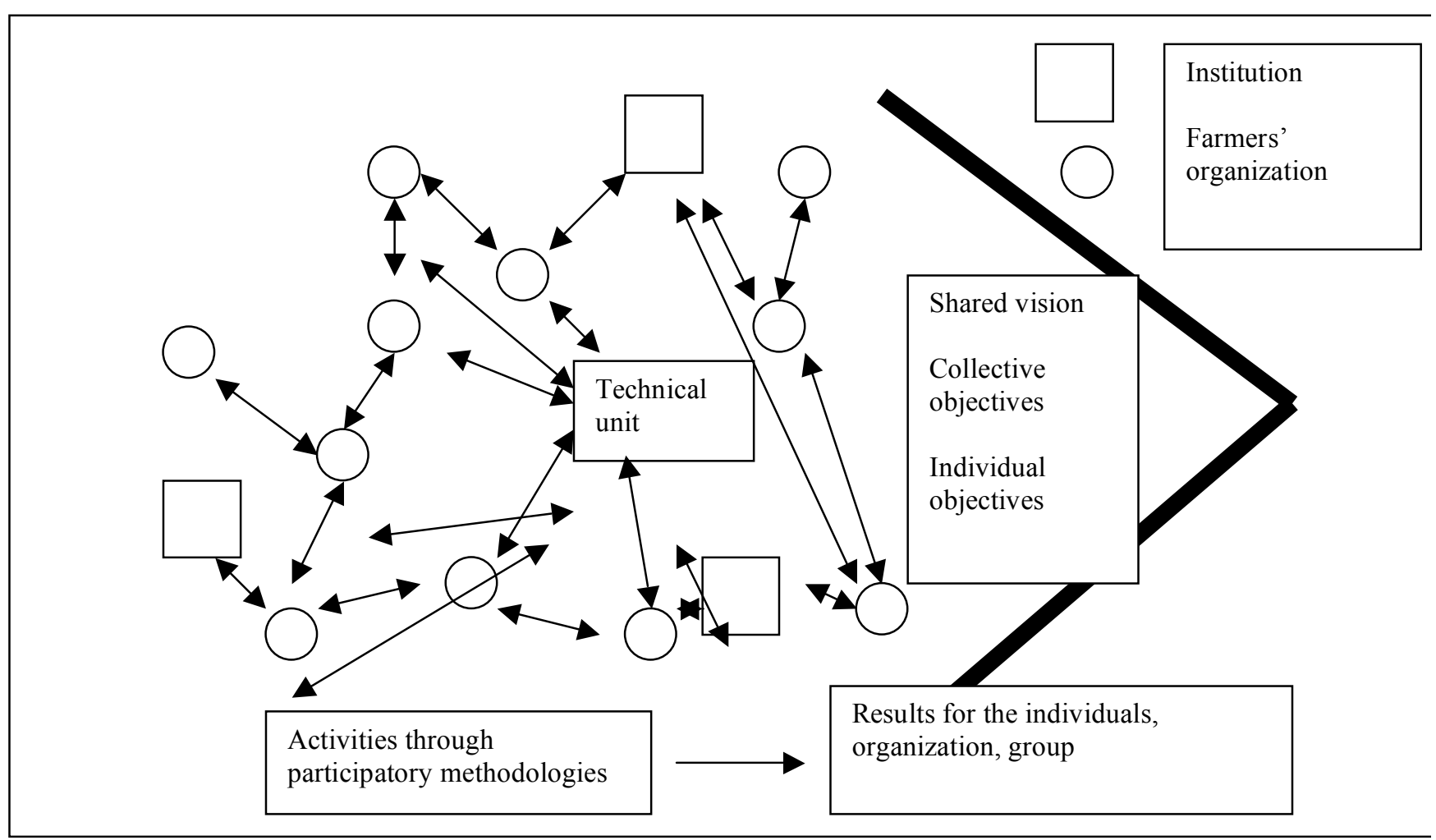

Fig 1: Relationships between farmers' organizations and other actors involved in collective action

\section{What are the most important principles of collective actions?}

A collective action can be characterized through an analysis of (i) the relationships between the collective or individual actors, (ii) the creation of knowledge and rules generated along a learning process. The implementation of such a collective action is based on the use of participatory methods and mechanisms to facilitate the collective action monitored by the actors.

According to these elements, the collective action assisted by the research-action program mobilizes different principles such as (i) producing a shared vision of the future of peasant agriculture based on the farmers' point of view to elaborate and negotiate farmers' proposals, (ii) strengthening the relationships between farmers' organizations, (iii) strengthening the relationships between farmers' organizations and others actors, (iv) creating links between actors who intervene at different levels (local, regional and national level) to address the problems at the correct level, (v) improving the internal functioning of farmers' organizations and the human capacities of the farmers' representatives and members, (vi) managing to resolve urgent problems which the farmers' face in the short term and identifying sustainable solutions in the long term, and (vii) implementing mechanisms and rules which improve farmers' participation in the research-action program monitoring. 


\section{To produce a shared vision of the future of peasant agriculture}

At the regional level the research-action program aims to (i) elaborate a shared vision between farmers' organizations of peasant agriculture in the Huetar Norte region and (ii) design a proposal for the future, including political perspectives, concrete recommendations, and projects. This work with a group of farmer's representatives includes meetings on specific topics and workshops with grassroots farmers' organizations. It mobilizes farmers' unions and public institutions to have an access to different information sources, to generate debates among the participants at different level and to create new knowledge.

It is difficult to get farmer's organizations to share a common vision. Some of these are dynamic organizations dealing with export products and are more concerned with the market, improving competitiveness and obtaining better prices. Others estimate getting government assistance to develop their own activities as more important (organizations based on food production in sectors in economic crisis). Still others put an emphasis on social relationships and how to promote economic activities to strengthen a specific group inside the rural communities (women's organizations, youth organizations...). Others want to promote more sustainable agriculture with fewer inputs and more autonomy to limit the external risks (environmental organizations).

According to prior meetings with farmers' organizations, the participants reached a first agreement between themselves. Agriculture must generate adequate incomes for a decent life through an efficient access to the market, protect families against economic risks by developing adapted farming systems, strengthen local employment and promote a sustainable development of the territory. However, this agriculture also must take into account the interests of the whole society which means to produce safe food, protect the natural resources, preserve the landscape and promote balanced development between rural and urban areas. This shared vision is an indispensable base for negotiating with the government concerning public policies that favor peasant agriculture. 


\section{VISION OF PEASANT AGRICULTURE IN THE HUETAR NORTE REGION OF COSTA RICA FROM THE FARMERS' ORGANIZATIONS POINT OF VIEW}

Generate incomes to obtain a decent living for our families

- Identify profitable products according to market needs and master the techniques

- Monitor the production costs in our farms

- Negotiate good prices and market access through our farmers' organizations

- Assure the possibilities of earning a decent living with agricultural and noagricultural activities for young people

Sell agricultural products of a good quality and produce added value for us

- Respect the quality norms derived from the markets by taking into account the Good Agricultural Practices

- Maintain different farming systems to obtain diversified agriculture

- Favor the local agro-industries and processing activities at the farm level to obtain better prices

- Regain a place in the local, regional and national markets to lessen dependence on the changing export markets.

Stimulate autonomy at the farm level to diminish risks

- Improve food production to feed our families and not buy food outside

- Produce more inputs inside the farm to avoid dependence and diminish costs

Generate local employment to strengthen the social tissue inside the rural space

- Maintain the number of farms

- Assure good working conditions for rural employees

- Develop new activities such as rural tourism to diversify incomes

Manage our natural resources

- Diminish the use of chemical inputs to limit pollution and improve our health

- Protect the soil to maintain our land fertility

Generate diverse services to Costa Rican society

- Protect the water and the rivers

- Maintain biodiversity

- Participate in carbon fixation

- Produce beautiful landscapes and spaces for tourist attractions

- Develop local knowledge and our rural culture

- Limit emigration to the cities

Build a local development process inside the rural communities

- Participate in the farmers' organizations and community activities

- Work with other actors inside or outside the agricultural sector to overcome difficulties

- Develop relationships with other farmers of Central America

- Strengthen our farmer identity in Costa Rica

Sources: meeting with farmers' organizations in June 2003, farm survey (Faure and Meneses, 2003) 


\section{To strengthen the relationships between farmers organizations}

Different activities strengthen the relationships inside and between the farmers' organizations themselves by generating new opportunities to exchange information, analyze a problem, identify objectives and design proposals.

In the context of the Northern region, this is a challenge characterized by strong individualism due to historical reasons. This region was a new frontier area until 20 years ago, with a strong heterogeneity between farmers (large national commercial farms, very large international farms, small scale farms very often located in the "asentamientos" ", agricultural employees often originating in Nicaragua). This situation favors the development of individual strategies and limits the elaboration of a collective vision inside the rural communities. Therefore, the main public institutions (MAG, IDA $^{* *}, \mathrm{CNP}^{\dagger \dagger}$ ) involved in rural development have specific relationships with some farmers' organizations to implement their own programs with paternalistic behavior limiting the autonomy of the farmers' organizations. This situation can be illustrated by the very high number of farmers' organizations that are weakened due to poor participation of members and the lack of leaders able to take into account the community's interests. It also can be illustrated by the importance of the conflicts between farmers' organizations to obtain access to a market on a competitive basis or to negotiate the resources distributed by the State. Mainly, this is due to different interests between large scale and small-scale farmers or different interests among the farmers depending upon the main crop they cultivate (pineapple, ornamental plants, beans...).

The program of activities at the level of farmers' organizations is mainly devoted to reinforcing the members' participation in the whole process (participatory diagnosis, elaboration of an action plan...) and re-thinking the role of the farmers' representatives.

The work on a common vision of peasant agriculture and other meetings with different farmers' organizations are opportunities to get to know each other, to exchange information, and to elaborate proposals. During these events there are talks between farmers' organizations to promote different types of unions to address some common problems. For example, as of this year, three organizations of small farmers want to design a common project to process and commercialize member's black beans in order to obtain better prices and payment conditions and avoid intermediary agents. Another example is the organization of meetings between regional farmers' organizations $\left(\mathrm{MNC}^{\$+}\right.$ and UPA Nacional $\left.{ }^{\S \S}\right)$ to elaborate a common proposal to disseminate the national farmers' organizations point of view about the new free trade agreement at the grass-roots level and to generate ideas and proposals to address this new context.

At local and regional levels, the different activities are aimed to improve the trust between the participants and to demonstrate the interdependence between them to reach some common objectives. This way the participants understand how the importance of reciprocity to strengthen the relationships and support a collective action.

\footnotetext{
${ }^{\S}$ Land property bought by the state and redistributed to farmers without land originating from different regions and sometimes from the cities. The "asentamientos" represent 40.000 ha in this region with 80.000 ha of agricultural land.

** Consejo Nacional de la Producción

${ }^{\dagger}$ Instituto de Desarrollo Agrario

\# Mesa Nacional Campesina

${ }^{\S}$ Unión de los Productores Pequeños Nacional
} 


\section{Strengthen relationships between farmers' organizations and others actors}

The research-action program facilitates the relationships between farmers' organizations and others stakeholders (government or private sector).

The work on a common vision of peasant agriculture modifies the relationships between farmers' organizations and the public institutions, which take the farmers' proposals more into account. This could be one of the most important impacts of the researchaction program. For example, in December 2003, a meeting took place between 10 farmers' organizations, a national farmers' organization (MNC) and high-level representatives of the Ministry of Agriculture to present challenges faced by farmers and some proposals to address these challenges. This event was an opportunity for some farmers' representatives to obtain access to decision makers to negotiate projects and produce concrete results.

Due to the asymmetry between the actors, the public institutions have always played a strong role and have an influence in the construction of the relationships and the decision making process. In some cases this has a positive effect, efficiently assisting farmers' organizations to define their objectives and implement activities according to those objectives. For example, for 4 years, the MAG assisted the young ornamental plants association of La Tigra which now has a high degree of autonomy and some successful activities (input credit distribution to its members and commercialization through direct exportation to avoid intermediary agents). In the majority of the cases, the technicians generate the dynamic and force decisions without strengthening the participation of members and the capacities of the leaders in a long-term process. The research-action program attempts to reverse this trend by strengthening the capacities of farmers' organizations to better negotiate with other actors.

\section{Create links between actors intervening at different levels}

It appears strategic to simultaneously strengthen the relationships between actors at different levels (local, regional and national level) to address the problems at the correct level.

There is a need to reinforce the links between the farmers' organizations at different levels. To elaborate a shared vision of the future of peasant agriculture and negotiate proposals, the group of farmers' representatives participating in this task decided in a workshop (i) to organize meetings at the community level to disseminate the information and take into account the farmers' point of view, (ii) to associate the regional office of the national farmers' organizations (MNC, UPA Nacional), and (iii) to contact these national farmers' organizations to obtain assistance and to facilitate contacts with the government and public institutions. Another good illustration is the alliance between farmers' organizations to commercialize black beans. The problem resolution implies to better organize production at the farm level, to develop alliances between a larger group of farmers' organizations at regional level in order to justify planned investments, and to negotiate financial resources and technical assistance at national level through the assistance of a national farmers' organization. 
There is also a need to reinforce the links between the different levels of public institutions to be sure that the agreements reached at the local level between farmers' organizations and public institutions would be accepted at a regional or national level and vice-versa.

\section{Improve the organization and human capital}

The research-action program works at the level of the farmers' organizations. The participatory diagnosis ${ }^{* * *}$ and monitoring improve a shared analysis between the members about the farmers' organizational situation. This work lead to the identification of principle problems, up-dates on the objectives of farmers' organizations, the definition of a program and proposed actions (training activities, project implementation...), and mechanisms (rules, institutional arrangements...) to achieve these goals. According to the general rules concerning collective action (Hatchuel 2000), this approach is aimed at producing a new perception of the situation between the members and thus generating new knowledge that provokes at this moment a modification in the relationships between the actors. Rodriguez (2003) addresses this issue in the case of the research-action program.

The research-action program works at the regional level on the shared vision of peasant agriculture by organizing different workshops. These workshops include a training dimension (exchanges of experiences, access to new information, personal work, oral presentations...). It helps the farmers' representatives to trust in their activities by strengthening self-estime, to trust in the organization by understanding how common are the difficulties, to obtain a better understanding of the environment. For example, a producer with responsibilities in a regional farmers' organization (UPA, Consejo regional de Guanacaste), participated in March 2003 in one of the meetings about CAFTA. He presented a paper using his own words about the issue and its impacts on peasant agriculture. He described a huge loss of jobs in the rural sector, without any job creation in other sectors able to compensate for this loss, rising emigration to cities and the USA, the increase of poverty in the poorest rural classes and the degradation of natural resources in some areas. After this presentation, a representative of the Ministry of Agriculture explained the expected advantages of this agreement from the government's point of view. A farmers' union representative from UPA Nacional presented the union position. The debate based on the different points of view strengthened the participants' capacities to analyze the problem. One concrete product of this meeting was the nomination of this farmer to the board of UPA Nacional, which was impressed by the quality of his analysis.

\section{Manage the short term to answer urgent demands and the long term to identify sustainable solutions}

The research-action program is involved in a long-term process to empower the farmers' organizations and to contribute to a better definition of the future of peasant agriculture in the national society. These goals are the bases to promote real change that can improve the living conditions of farmers. However, this takes time and the needs expressed by the farmers are more concrete and require immediate answers. So it is

\footnotetext{
*** The farmers' organization participatory diagnosis includes an analysis of it's history, activities, internal functioning, and external relationships; it includes regular meetings with a group composed of leaders and members; it includes debates with all the members to improve and validate the diagnosis.
} 
important to manage these two components at the same time. Only with rapid and concrete actions can the research-action program build the trust of the farmers and facilitate their participation in more complex activities with visible results after a longer period of time.

For example, the research-action program facilitates the elaboration of several projects presented by farmers' organizations to some donors or to implement special activities. As a result, the association JAZON ${ }^{\dagger \dagger \dagger}$ is now part of a rural tourism project aimed at facilitating the insertion of 70 families into this new activity. Special work is devoted to assist the members of the association APROPIÑA ${ }^{\text {ttt }}$ in implementing new norms to produce and export pineapple.

Such a strategy to manage the long and short term is not so easy to implement. There is a risk of dispersion of the activities and the loss of efficiency. There is also a risk in responding to demands that are not based on a real analysis of the priorities of farmers' organizations, which are presented only by some farmers' representatives without the real participation of all members. This could contribute to reinforcing the traditional and inadequate relationships between farmers' organizations and technicians.

\section{Set up new mechanisms and rules}

The research-action program designed and used well-known methods to facilitate the farmers' participation. For example, the diagnosis at the farmers' organization level includes the participation of different categories of farmers (board representatives and regular members, men and women...). The different workshops mobilize classical participatory tools such as the exchange of experiences between farmers or the utilization of cards to write personal ideas on a specific subject.

Beyond these practices, it is crucial to negotiate and implement mechanisms to guarantee real participation in the monitoring of the research-action program at different levels. To implement farmers' governance, some interesting elements already exist but there is a need to improve the entire monitoring system. The research-program plans to facilitate the implementation of a regional farmers' organization platform aimed at promoting the exchanges between farmers on common interest topics and identifying collective activities. This platform could be a mechanism to transfer power to the farmers for monitoring the research-action program. However, the lack of trust between the main national farmers' organizations and the resistance of the public institutions to facilitate a union between farmers' organizations could impede a rapid concretization of this objective. It takes time to improve the trust between the actors.

For one year, a technical unit composed of several technicians and farmers' representatives worked together to monitor the research-action program to directly take into account the farmers' demands. These farmers' representatives participated in different activities with the technicians and facilitated the relationships between the technicians and all the farmers' organizations. Some months ago, this initiative was stopped because of different problems such as inadequate meeting planning and imprecise individual function definitions. Recently, some farmers' representatives

\footnotetext{
†† Jóvenes Agricultores de la Zona Norte

H* Asociación de Productores de Piña de Pittal
} 
requested the reactivation of this technical unit but with a need to improve the rules of operation.

\section{How to extend the collective action}

The presentation of the different principles generates a question. How to assure a collective action that can reach the large common objectives as defined by the participants when the research-action program involves a small number of farmers' organizations and has few resources in terms of personnel and budget?

One part of the response is linked to the capacity of identifying and working with the key actors, who can actively participate in the collective action and induce a dynamic beyond their organization or institution. On one hand, this choice implies the involvement of leaders with relevant responsibilities in the farmers' organizations and farmers' organizations with strong political or economic influence. On the other hand, it implies involving technicians with commitments and abilities to work with farmers and institutions, who are able to provide assistance and have a good institutional network. At this point, there is a need to better understand what are the variables, which constitute the reputation of each actor, in the sense of Ostrom's criteria (1998). In fact, the participation of these key actors depends upon some times contradictory different factors. First of all, the collective action construction (problem definition, objective identification, proposal elaboration) must generate by itself the key actors' participation on a voluntary basis with respect to the choices of the farmers' organizations and institutions. The role of the technicians, especially those involved in the research-action program, is crucial to creating the conditions to attract these key actors with a risk of generating strong disturbances.

The intensity of the collective action is also linked to the capacity of stimulating the union between farmers' organizations to facilitate information dissemination, reduce the transaction costs, and improve the economic and political power. The form of these unions depends upon the problem addressed and the quality of the relationships between farmers' organizations based on the parameters of trust, reciprocity and reputation. The forms of theses unions could be different (formal or informal, union or federation, longterm or short-term alliance).

The collective action could have a strong impact by generating some changes in the public institutions to better address the farmers' needs and then achieve positive results for a larger number of producers. For example, the Ministry of Agriculture is organizing a congress to address the public assistance mechanisms to farmers' organizations and propose improvements. The research-action program is facilitating the farmers' participation in this congress to promote some farmers' proposals and thereby extend the influence of this collective action.

\section{Conclusion}

The collective action assisted by the research-action program aimed at (i) producing a shared vision of the future of peasant agriculture based on the farmers' point of view to elaborate and negotiate farmers' proposals and (ii) strengthening the relationships between farmers' organizations and with other actors. It is crucial to generate actions (i) at the grass-roots level to empower the organizations themselves and to build human 
capacities, (ii) at the regional and national levels to facilitate the union between farmers' organizations, and (iii) to tackle both short-term and long-term issues.

This collective action is based on mechanisms and rules that improve the farmers' participation in the research-action program, facilitate the interactions between individuals and farmers' organizations, and guarantee adequate activity monitoring.

This research-action program takes place in a difficult context with both a liberalization process and a trans-nationalization of agriculture that induces discouragement among farmers and strong rural emigration. These conditions limit the research-program's positive results. Beyond this fact, it seems difficult to carry out an impact assessment now. Such a collective action is a long-term process and it takes time to observe the results derived from the research-action program. Moreover, most of the impact concerned the empowerment of individuals and organizations whose effects could be very diverse.

\section{References}

Elster J. (1990) Racionalidad, Moralidad y Acción colectiva, Zona Abierta, Vol. 54/55, pp.43-67.

Faure G. and Meneses D. (2003) Las fincas en la región Huetar Norte: una evaluación de las condiciones actuales de las fincas de las familias campesinas. Simposio : "Problemática actual, procesos históricos y visión prospectiva del agro en la zona norte" UCR-UNA. 3 de febrero. San José, Costa Rica. 10 p.

Hatchuel A. (2000) Quel horizon pour les sciences de gestion? Vers une théorie de l'action collective, In «Les nouvelles fondations des sciences de gestion», Paris, Vuibert, pp. 7-43.

MAG/CIRAD (2003) Nuestra Agricultura Tiene Futuro. Programa MAG/CIRAD de fortalecimiento de las organizaciones de la región Huetar Norte. El enfoque de la Investigación, MAG/CIRAD, $8 \mathrm{p}$.

Ostrom E. (1998) A behavioral approach to the rational-choice theory of collective action, American Political Science Review, Vol. 92, No 1, pp 1-22.

Rodriguez, N. (2003) Caracterización y diagnostico de las organizaciones campesinas de la región Huetar Norte: una propuesta de fortalecimiento a través de la participación. In the simposio "Problemática actual, procesos históricos y visión prospectiva del agro en la zona norte, 2-3 diciembre, UCR, San José, 20 p.

Ramírez, E., Berdegue J. (2003) Acción colectiva y mejoras en las condiciones de vida de las poblaciones rurales, RIMISP, Chile, $10 \mathrm{p}$. 


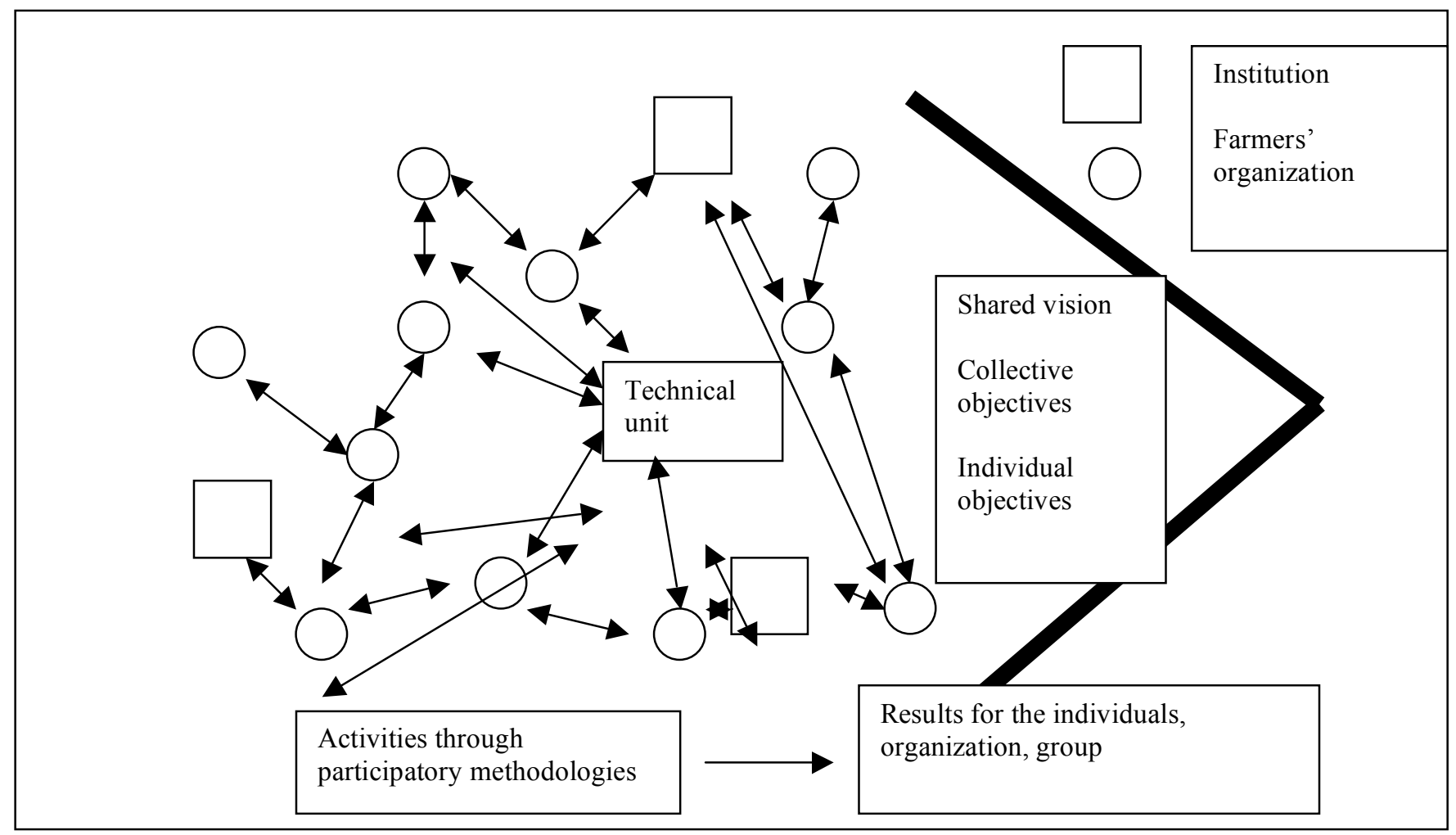

Fig 1: Relationships between farmers' organizations and others actors involved in the collective action 